\title{
STRUCTURAL, MORPHOLOGICAL AND OPTICAL PROPERTIES OF NANOPRODUCTS OF ZIRCONIUM UNDER LASER ABLATION IN WATER AND IN AQUEOUS SDS SOLUTIONS
}

\author{
Karpukhin Vyacheslav Timofeevich
}

Doctor of Technical Sciences, Chief Researcher, Laboratory of Physical Modeling of Two-Phase Flows, Joint Institute for High Temperatures of RAS vtkarp@gmail.com Izhorskaya St., 13, 125412 Moscow, Russian Federation

\section{Malikov Mikhail Maksimovich}

Doctor of Technical Sciences, Leading Researcher, Laboratory of Physical Modeling of Two-Phase Flows, Joint Institute for High Temperatures of RAS vtkarp@gmail.com Izhorskaya St., 13, 125412 Moscow, Russian Federation

\section{Borodina Tatyana Ivanovna}

Candidate of Physical and Mathematical Sciences, Senior Researcher, Laboratory of Shock Wave Effects,

Joint Institute for High Temperatures of RAS

vtkarp@gmail.com

Izhorskaya St., 13, 125412 Moscow, Russian Federation

\section{Valyano Georgiy Evgenyevich}

Senior Researcher, Laboratory of Shock Wave Effects, Joint Institute for High Temperatures of RAS vtkarp@gmail.com

Izhorskaya St., 13, 125412 Moscow, Russian Federation

\section{Gololobova Olesya Aleksandrovna}

Research Assistant, Laboratory of Physical Modeling of Two-Phase Flows, Joint Institute for High Temperatures of RAS

vtkarp@gmail.com

Izhorskaya St., 13, 125412 Moscow, Russian Federation 


\title{
Strikhanov Dmitriy Andreevich
}

Postgraduate Student, Laboratory of Physical Modeling of Two-Phase Flows, Joint Institute for High Temperatures of RAS

vtkarp@gmail.com

Izhorskaya St., 13, 125412 Moscow, Russian Federation

\begin{abstract}
The paper deals with structural, morphological and optical properties of nanoproducts which undergone zirconium laser ablation in water and in aqueous SDS solutions. Depending on experiment conditions the indicated products can appear as different crystalline phases of zirconia and organic-inorganic composites, which include SDS alkyl chains intercalated between layers of zirconium oxides or hydroxides. The formation of zirconium dioxide-based hollow nano- and microstructures is demonstrated. It is suggested that ablation-formed gasvapor bubbles can serve as templets for generation of hollow structures.
\end{abstract}

Key words: laser ablation, metal nanocompositions, zirconium dioxide, RAMAN spectra, gas-vapor bubbles.

Numerous publications devoted to both synthesis and investigation of properties of nano dispersed zirconia have appeared by now [12, 17, $34,46,49,52,54,63]$. The interest is determined by unique mechanical, chemical, optical and other properties that open way to a broad practical application of the material in science and technology $[7,26,10,60,64]$. Synthesis of oxides and other metal nanocompositions by laser ablation in a liquid environment is one of perspective methods [25, 30, 58]. However, the data on zirconia generation by the mentioned way is far not sufficient $[11,14,15,19,33]$. The experiments were carried out mainly at low laser pulses repetition rate $(\sim 10 \mathrm{~Hz})$, that limits the perspective of establishing productive technologies, potential investigations of a number of physical and chemical processes accompanying the synthesis and affecting properties of the final product.

Thus, the given work is devoted to the attempt of generating nanocrystalline zirconia by laser ablation of zirconium target in aqueous solutions of a surfactant. A copper vapor laser (CVL) with the power output $10-15 \mathrm{~W}$, radiation pulse duration $20 \mathrm{~ns}$, and pulse repetition rate $10 \mathrm{kHz}$ was used as radiation source.

\section{Experimental section}

Physical and technical descriptions of laser ablation in liquid are given in detail in numerous original articles and reviews $[8,53$, 70]. CVL generation was performed at two wave lengths: 510.6 and $578.2 \mathrm{~nm}$, line power ratio was correspondingly $2: 1$. UV light $(255$, 271 and $289 \mathrm{~nm}$ ) was obtained by nonlinear conversion of the $\mathrm{Cu}$ laser radiation (510.6 and $578.2 \mathrm{~nm}$ ) in a BBO crystal [3]. The laser beam was focused on the target surface by an achromatic lens with focal distance of $f=280$ $\mathrm{mm}$, that provided the spot diameter of less than $100 \mu \mathrm{m}$. The target was placed into a glass cell with deionized water or aqueous solutions of a surfactant. The volume of the liquid in the cell was $\sim 10 \mathrm{~cm}^{3}$. The cell was placed in a vessel with cooling water, its temperature was kept at $\sim 300 \mathrm{~K}$. The vessel was installed on a movable table that permitted to constantly move the focal spot over the target surface. The surfactant SDS $\left(\mathrm{C}_{12} \mathrm{H}_{25} \mathrm{SO}_{4} \mathrm{Na}\right)$ of anionic group was used for the experiment.

The optical characteristics of colloidal solutions with nanostructures of zirconia were analyzed by the absorption spectral method in the range of $200-00 \mathrm{~nm}$ by SF- 46 spectrophotometer with automatic data processing. RAMAN Spectra were recorded by double monochronomator KSVU-23. The structure and composition of the solid phase extracted from the colloid solution after centrifugation at $15000 \mathrm{rpm}$ and evaporation at $320-330 \mathrm{~K}$ were analyzed at X-ray diffractometer DRON-2 ( $\mathrm{K}_{\alpha}$ copper line). Shapes and sizes of nanostructures were determined by Hitachi S405A scanning electron microscope at accelerating voltage of $15 \mathrm{kV}$, according to the standard technique. 


\section{Results and discussion}

XRD data. The experiments were performed both in deionized water (SDS solution molarity $\mathrm{M}=0$ ) and at $\mathrm{M}=0.0001,0.01,0.05$ and 0.1. Exposition time of radiation onto the target $\tau_{\exp }$ were varied within intervals from 5 to 180 min. In a number of cases the properties of colloid and its solid phase were analyzed tens hours later (the aging time). Fig.1 demonstrated typical XRD patterns of solid phase of colloids at $\mathrm{M} \mathrm{SDS}=0$, $0.01,0.05$ and 0.1 . After ablation of zirconium in deionized water the synthesized zirconia was mainly in X-ray amorphous state, i.e. the size of the crystallites did not exceed 1-2 nm (curve 1). The crystalline part of the solid contains 5-9 vol. \% of monoclinic phase, 4 vol. \% of tetragonal phase and about 3 vol. \% of metal zirconium. Sizes of metal zirconium crystallites make not less than $100 \mathrm{~nm}$, of monoclinic phase $\sim 40-75 \mathrm{~nm}$ and of tetragonal phase $\sim 60-100 \mathrm{~nm}$. Sizes of nanoparticles become less with the increase of exposition time. Crystalline lattice parameters of dioxide tetragonal modification stay within the limits of $\mathrm{a}=0.05083-0.5093 \mathrm{~nm}, \mathrm{c}=0.5127$ $0.5185 \mathrm{~nm}$, with ratio c/a varies from 1.007 (close to cubic structure) to 1.019 . It is supposed that ions of $\mathrm{OH}^{-}$appearing in the process of ablation can serve as a stabilization factor for tetragonal phase at $\mathrm{M}=0$. It is supported in other similar experiments [27, 57]. We can observe a tendency of extending monoclinic phase along with exposition time growth and reduction of metal zirconium amount.

At $\mathrm{M}=0.01$ a greater part of colloid solids is in the amorphous state, as well. The crystalline part consists of SDS, monoclinic, tetragonal phases and a small part of metal zirconium. The ratio of monoclinic and tetragonal phases makes $\sim 1.6: 1$. Lattice parameters of tetragonal phase are: $\mathrm{a}=$ $0.5115 \mathrm{~nm}, \mathrm{c}=0.5133 \mathrm{~nm}$, i.e. the lattice is close to cubic. Sizes of monoclinic phase particles are $60-$ $100 \mathrm{~nm}, 45-100 \mathrm{~nm}$ for tetragonal one. At the increase of ablation time up to $180 \mathrm{~min}$, the crystalline part enhances. The monoclinic phase makes about 8 vol. \%, the tetragonal phase is about 7 vol. \%. Tetragonal phase average size equals to about $60 \mathrm{~nm}$, that of monoclinic phase is about 80 $\mathrm{nm}$. The increase of SDS concentration to $\mathrm{M}=$ 0.05 does not practically change XRD patterns structure. Similar to $\mathrm{M}=0.01$, about $2.5 \mathrm{vol} . \%$ of zirconium is presented. Average size of particles for both parts of dioxide and metal zirconium reduces to $40-45 \mathrm{~nm}$. The reduction of crystallite average sizes at $\mathrm{M}=0.01$ and 0.05 with regards to crystallite sizes at $\mathrm{M}=0$ is caused by the influence of surfactant - SDS, which restricts nanoparticles growth $[28,29]$. The presence of SDS in the initial solution creates prerequisites for the appearance of the third high temperature phase of zirconia, i.e. a cubic phase. Thus, in experiments at $\mathrm{M}=0.01$, $0.05,0.1$ phases with lattice spacing of $\mathrm{a}=0.5127$ $\mathrm{nm}, 0.5115 \mathrm{~nm}$ and of $\mathrm{c}=0.513 \mathrm{~nm}$ were presented, i.e. phases close to cubic ones. Tetragonal and cubic phases can be stabilized by anions $\mathrm{OH}^{-}$, anions $\mathrm{SO}_{2}^{-}, \mathrm{SO}_{3}^{-}, \mathrm{SO}_{4}^{-}$of SDS which appear during ablation time, interact with crystalline surface and prevent oxygen penetration, as well as cations $\mathrm{Na}^{+}[26,27]$. At the concentration of SDS in solution up to $\mathrm{M}=0.1, \mathrm{XRD}$ patterns are observed as a spectra of well crystallized SDS, a considerable part of which is oriented along the surface of glass plate (plane 00L), a smaller part is distributed chaotically (fig. 1, curve 2). Along with lines belonging to SDS and $\mathrm{ZrO}_{2}$ the XRD spectrum has a number of other maxima, their intensity considerably surpasses intensity of zirconia lines, though it is weaker than SDS maxima. Some of those lines can be attributed to hydrate SDS $\cdot \mathrm{H}_{2} \mathrm{O}$ and $\mathrm{Na}_{2} \mathrm{~S}_{2} \mathrm{O}_{3} \cdot \mathrm{H}_{2} \mathrm{O}$. The spectrum also clearly demonstrated the phase with interlayer distance $\mathrm{d}=5.165 \mathrm{~nm}$. Distances close to the indicated ones are typical of organic-inorganic composites with alkyl chains intercalated between oxide or hydroxide layers of transition metal $\mathrm{Zn}, \mathrm{Co}, \mathrm{Fe}, \mathrm{Cu}$, etc [44]. The chains may be placed perpendicular to oxide or hydroxide layers and tilting, as well, besides, the chains are connected between themselves by hydrocarbon "tails". They may be partially interdigitated. Thus, formation of one-layer and two-layer structures with broad variation of parameters $\mathrm{d} \sim 0.25-6 \mathrm{~nm}$ is possible. The formulas of such compositions are as follows: $(\mathrm{M})_{2}(\mathrm{OH})_{3} \mathrm{X} \cdot \mathrm{z} \cdot \mathrm{H}_{2} \mathrm{O}$ and $(\mathrm{M})(\mathrm{OH})_{2} \mathrm{X} \cdot \mathrm{z} \cdot\left(\mathrm{H}_{2} \mathrm{O}\right)$ for hydroxides and $\mathrm{X} \cdot \mathrm{M}^{2+} \cdot \mathrm{Z} \cdot\left(\mathrm{H}_{2} \mathrm{O}\right) ; \mathrm{X} \cdot \mathrm{M}_{2} \mathrm{O}^{2+} \cdot \mathrm{z} \cdot\left(\mathrm{H}_{2} \mathrm{O}\right)$ for oxides, where $\mathrm{M}$ is divalent metals $(\mathrm{Zn}, \mathrm{Cu}$, $\mathrm{Zr}), \mathrm{X}$ is intercalated anion alkyl sulfate $\left(\mathrm{C}_{\mathrm{n}} \mathrm{H}_{2 \mathrm{n}+1}\right.$ $\mathrm{SO}_{4}$, where $\mathrm{n}=12$ ), $\mathrm{z}$ is molecules number of $\left(\mathrm{H}_{2} \mathrm{O}\right)[24,44]$. The authors have already obtained similar $\mathrm{Zn}$ and $\mathrm{Cu}$ composites during ablation of the indicated metal targets in aqueous SDS solutions [20, 24]. 
Long exposition of radiation in colloid may cause breaking of SDS molecules, that formed new phases $-\beta-\mathrm{Zr}\left(\mathrm{SO}_{4}\right)_{2}$ and $\beta-\mathrm{Zr}\left(\mathrm{SO}_{4}\right)_{2} \cdot \mathrm{H}_{2} \mathrm{O}$ in the spectrum [6]. It should be emphasized that a specific feature of the experiment is predominance of synthesized zirconia in amorphous state mainly.

RAMAN spectra. The spectrum obtained at $\mathrm{M}=0$ shows the presence of monoclinic, tetragonal and cubic phases of $\mathrm{ZrO}_{2}$ in solid part of colloid (fig. 2). While comparing the spectra taken at $\mathrm{M}=0.1$ and deionized water (fig. 3), at $\mathrm{M}=0.1$ we see peaks in the region of $2000-$ $2400 \mathrm{~cm}^{-1}$ and $2800-3000 \mathrm{~cm}^{-1}$, that can be attributed to a vibrational structure of $\mathrm{Zr}(\mathrm{OH})_{4}$ molecule. Fixation of zirconium oxide and hydroxide in RAMAN spectra at $M \geq 0.01$ together with XRD data most obviously speaks in favor of synthesis of organic-inorganic composite $\mathrm{Zr}-$ SDS, consisting of zirconium oxide or hydroxide layers with intercalated SDS alkyl chains.

Morphology of synthesized products. Figs.

4, 5 present images of solid phase structures of colloid at different $\tau_{\exp }$ and SDS solution molarity $M$. The treatment of samples synthesized in deionized water $(\mathrm{M}=0)$ at $\tau_{\text {exp }}=5,20,180 \mathrm{~min}$ showed that they consist of separate large particles (up to $10 \mathrm{Mm}$ ), aggregates of rounded particles ( $100-500 \mu \mathrm{m})$ and dense mixture of grains with poorly defined boundaries (fig. 4a). The latter ingredient of the microstructure is more typical for $\tau_{\text {exp }}=180 \mathrm{~min}$, where it is main, X-ray amorphous component. At $\tau_{\exp }=5$ and $20 \mathrm{~min}$ it can be observed that in the structure among large and small particles there are spherical hollow units with sizes from tens $\mathrm{nm}$ to several $\mu \mathrm{m}$, some of them concave and partially broken (fig. 4b, 4c). The cover of large hollow particles consist of separate layers, the thickness of the cover can be within 50-200 nm and more (figs. 4a, 4d). That correlates with the XRD data for an average size of nanoparticles $(\sim 40$ $100 \mathrm{~nm}$ ) that build up microstructures.

The crystalline part of the solid phase extracted from colloid is significantly changed when SDS is added to the initial solution. It is known that micellae (Hartley type) start to appear in the solution, if SDS concentration exceeds the critical level $(\mathrm{M} \sim 0.008 \mathrm{~mol} / \mathrm{l})$. With the increase of $\mathrm{M}$ crystals begin to grow. In accordance with Wolf principle, chain-like structure of SDS molecule predetermines that crystals are formed either as thin elongated plates for SDS anhydrite or monohydrite, or as octahedral-like plates for $\mathrm{C}_{12} \mathrm{H}_{25} \mathrm{OSO}_{3} \mathrm{Na} \cdot 1 / 8 \mathrm{H}_{2} \mathrm{O}$ [34]. After aging of colloid for tens hours the images show crystals in the shape of long sticks (fig. 5b). The abovementioned plate units may serve as templets to form laminar structures of organic-inorganic composites based on zirconium oxides or hydroxides. When exposition exceeds $5 \mathrm{~min}$, pictures show zones of crystallized SDS structures, areas of amorphous SDS and zirconia and droplets of aggregates or separate large solid and hollow zirconia nanoparticles.

Hollow nano and microspheres are observed at all regimes of zirconium target ablation both in deionized water and in SDS solution (fig. $4 c$, fig. 5d). However, at $M=0$ average sizes of hollow particles are noticeably larger than at $\mathrm{M}$ $\geq 0.01$. Some publications consider adsorption of nanoparticles on the surface of vapor-gas bubbles to be a basic mechanism for formation of hollow structures, i.e. the gas bubble serves as a "soft" templet [65-68]. There might be several reasons for bubble formation. There are certain zones in the focal spot on the target surface due to space and time power distribution over beam area: ablation $\left(\geq 10^{8} \mathrm{~W} / \mathrm{cm}^{2}\right)$, melting $\left(<10^{8} \mathrm{~W} / \mathrm{cm}^{2}\right)$, surface heating above liquid boiling point [39]. The ablation produces a plasma-vapor-gas bubble, its collapse may create secondary gas $\left(\mathrm{H}_{2}, \mathrm{O}_{2}\right)$ and vapor bubbles [29, 38, 71]. The process generates both heated solid particles and metal droplets with a vapor cloud around them [62]. Besides, in passing through the laser beam particles may get heated up to temperatures above the melting point, break to small fragments, and it is accompanied by vapor bubbles formation [43]. The main reason for appearance of a solid shell on gas bubble surface is the adsorption of solid particles on the gas - liquid boundary (capillary effect). It leads to decreasing the surface energy of the bubble-particle system:

$$
\Delta \mathrm{E}=-\pi \mathrm{R}^{2} \gamma(1-\cos \theta),
$$

where $\mathrm{R}$ is a particle radius, $\gamma$ is surface energy of a gas bubble (water - gas boundary), $\theta$ is a contact angle of the particle with the bubble surface. Angle $\mathrm{E}$ is $<90$, as particles of metal oxides are hydrophilic. Calculation shows that for $\mathrm{R}=2 \mathrm{~nm}, \gamma \approx 74 \cdot 10^{-3} \mathrm{H} / \mathrm{m}$ and и $\theta \approx 40^{0}$, $|\Delta \mathrm{E}| \approx 12.3 \mathrm{kT}$, i.e. considerably higher of the particles heat energy at $\mathrm{T} \sim 300 \mathrm{~K}[4]$. In other words, the separation of particles from the surface is hindered. 
The initial layer of adsorbed particles grows due to Oswald effect and finally forms a layered shell $[40,45]$. Its growth rate depends on of particles diffusion rate in liquid. SDS presence in the solution will increase its viscosity, retard particle diffusion and, therefore, will prevent the growth of shell sizes. Shell formation does not occur only because of small nanoparticles of zirconia. In the presence of SDS we can observe separate attached SDS crystallites and, possibly, crystallites of $\mathrm{Zr}-$ SDS composite (fig. 5b). When drifting in the colloid nanostructures in the area of laser beam, it leads to fusion of their surface layer (fig. 5c) [21, 67]. It is noteworthy, that high pulses repetition rate makes the generation of vapor-gas bubbles go very intensively, thus, the possibility of hollow nano and microstructure formation is increased. Kircandle effect might be observed for particles with "nucleus-shell" structure, where the nucleus may be metal and the shell made of another material (metal oxide, etc.) [55], that leads to cavities formation inside particles due to differences of component diffusion rate. The formation time may make up to several minutes [51] and it goes down noticeably when particles are heated. In this regard, the appearance of such particles in the experiments is highly probable. Both effects can be a cause for appearing "rattle" structures (fig. 5d) (smaller spheres are inside a lager one) [37]. It should be noted that the indicated hollow nano and microspheres at laser ablation of zirconium in water and aqueous solutions of SDS seem to be obtained for the first time.

Optical characteristics. Absorption spectra. Zirconia is a wide band gap insulator with two direct transmissions between zones of valence and conductivity of 5.2 and $5.79 \mathrm{eV}$ [54]. Upper levels of the valence zone are mainly of $\mathrm{O}(2 \mathrm{p})$ type and lower levels of the conductivity zone are determined by $4 \mathrm{~d}$ orbitals zirconium ion $\mathrm{Zr}^{4+}[55,56]$. Changes of phase composition of $\mathrm{ZrO}_{2}$ and the synthesis conditions, presence of surfactant, in particular, influence of the absorption spectra that carry information about the structure of the formed crystalline lattice and its intrinsic and surface defects, vacancies, other inclusions $[57,58]$. The investigation of absorption curves (fig. 6,7 ) of the colloid solution obtained at 5 and 20 min target ablation in deionized water and aqueous SDS solution reveals some peculiar features of the spectrum:
- steep rise of absorption in UV range $\sim 200$ $240 \mathrm{~nm}$. The rise is observed both at $\mathrm{M}=0$ and $\mathrm{M} \neq 0$. When $\mathrm{M}=0$ the above mentioned zone of absorption can be divided into two. The 200-220 spectrum region has a higher average absorption level and typical peaks at 200, 205, 210-212 nm, that are most dramatic at 5 minute exposition (fig. 6 , curve 1), and the $220-240 \mathrm{~nm}$ region with the absorption level 20 - $25 \%$ lower;

- zone of absorption rise (5-7\%) within the region of $240-350 \mathrm{~nm}$ with peaks at 270 , 300,325 and $350 \mathrm{~nm}$ (fig. 6, curves 1, 3, 5; fig. 7, curves $1,3,5,6$ );

- absorption dips ("bleaching") in narrow spectrum interval at the beginning $(245-255 \mathrm{~nm})$ and at the end $(\sim 355 \mathrm{~nm})$ of the mentioned region (fig. 6 , curve 1,4 , 5; fig. 7 , curves $3,5,6$ );

- increase (3-4\%) of absorption within the interval of 440-480 nm with maxima at 445, 460 $470 \mathrm{~nm}$ (fig. 6, curves 1, 4, 5).

The increase of ablation time and SDS concentration in solution gives a considerable rise of absorption level, especially in the long wave spectrum range, due to particle concentration growth. At that it does not change much within the wave range of $350-600 \mathrm{~nm}$, that is typical of colloids with formed fractal structures of the solid phase [24, 59]. Colloid aging for 24 hours and longer does not practically change spectrum shape in the initial region of $200-260 \mathrm{~nm}$ (fig. 6 , fig. 7 curve 3,5 ). However, beyond this boundary the absorption decreases towards longer wave lengths, and the final level is considerably lower. That speaks to sedimentation of large units of the colloid solid phase.

The analysis of the mentioned features of the absorption spectrum with consideration of the phase mixture (cubic, monoclinic and tetragonal phases) and dimensional composition of $\mathrm{ZrO}_{2}$ nanoparticles $(40-100 \mathrm{~nm})$ leads to the following conclusions. The steep rise of absorption in UV range from 200 to $240 \mathrm{~nm}$ seems to be associated to $\mathrm{O}^{2-}(2 \mathrm{p}) \rightarrow \mathrm{Zr}^{4+}(4 \mathrm{~d})$ transitions. Similar phenomenon was observed in a number of other research $[54,55]$. The spectrum region at 200 $220 \mathrm{~nm}$ is determined by the presence of cubic and tetragonal phases, and of metal zirconium, as well. It is shown by typical absorption peaks at 200, 205, 210-212 $\mathrm{nm}[60,61]$. The appearance of monoclinic phase means the transformation of crystalline lattice structure, its symmetry. 
Coordination number of zirconium ions at transition from tetragonal to monoclinic phase changes from 8 to 7 . This change leads to a split of $4 \mathrm{~d}$ levels of $\mathrm{Zr}^{4+}$ ion and the appearance of long wave branch in $\mathrm{O}^{2-}(2 \mathrm{p}) \rightarrow \mathrm{Zr}^{4+}(4 \mathrm{~d})$ transition spectrum, i.e. the boundary of absorption band shifts to the red region up to 240-250 $\mathrm{nm}$ [54].

The band gap of zirconia $\mathrm{E}_{\mathrm{g}}$ is calculated from the dependence of the absorption coefficient $(\alpha)$ on the photon energy ( $h v)$ in the band-edge spectral region for a direct transition by a known formula:

$$
\alpha h v=\text { const }\left(h v-\mathrm{E}_{\mathrm{g}}^{\text {bulk }}\right)^{1 / 2}
$$

where, $\mathrm{h}$ is Plank constant, $\mathrm{E}_{\mathrm{g}}$ bulk is the band gap of the solid [64]. It gives values for samples obtained at ablation on deionized water $\sim 5.27 \mathrm{eV}$ and $\sim 5.76 \mathrm{eV}$ that is close to the mentioned above. The increase of SDS concentration in solution up to $\mathrm{M}=0.1$ reduces $\mathrm{E}_{\mathrm{g}}$ to the level of $\sim 4.54$ and $4.78 \mathrm{eV}$. This fact is determined by growth of lattice defects at $\mathrm{M} \neq 0$.

Zirconia, representing photoresistant metal oxides, posesses a typical property to capture charge carriers (electrons and holes) by crystalline lattice defects [63] with the formation of centers of absorption ( $\mathrm{F}, \mathrm{V}$ colour centers) or luminescence $[63,64]$. Under the influence of radiation of a certain wavelength range the captured electrons or holes get free and recombine, in particular, by radiative emission, i.e. color (absorption) centers disappear. In that case gaps ("bleaching" zones) appear in absorption spectrum within rather narrow wavelength range. We should note that the process of nanostructure synthesis at metal ablation in liquid by nanosecond pulses is far from equilibrium. The presence of SDS molecules and ions in the solution also increases potential generation of defects inside and on the surface of crystals. With this point of view, gaps in spectra presented in curves $1,4,5$ (fig. 6) and 3, 5, 6 (fig. 7) at wavelengths of 245$255 \mathrm{~nm}$ and $\sim 355 \mathrm{~nm}$, enhanced absorption in regions of $240-350 \mathrm{~nm}, 440-480 \mathrm{~nm}$ and 540 $600 \mathrm{~nm}$ can be attributed to the discussed above character. Similar facts were observed and discussed in [57].

Photoluminescence. Figs. 8, 9 give colloid spectra obtained at different excitation wavelengths and SDS molar fractions in the initial solution. The spectra (fig. 7, curves 1,3 ) excited by UV radiation $\left(\lambda_{\text {exc }}=271 \mathrm{~nm}\right)$ in colloids with $\mathrm{M}=0.05$ and 0.1 take up a rather continuous region in wavelengths of 340-610 $\mathrm{nm}$. In both cases two parts are obviously specific: $310-400 \mathrm{~nm}$ and $400-535 \mathrm{~nm}$. Maximal level of the signal in the second region is about 1.5-2.0 times higher. Moreover, luminescence intensity for the spectrum in general at $\mathrm{M}=0.1$ is higher than at $\mathrm{M}=0.05$. In the absence of SDS, firstly, the general level of luminescence goes down by several times, secondly, the spectrum starts from $330 \mathrm{~nm}$. In this case we can see several regions of enhanced luminescence: $360,420-425$, $435-450 \mathrm{~nm}$. Spectra maxima at $M \neq 0$ are shifted into the red region by $\sim 50-60 \mathrm{~nm}$ and have flatter wide top. In the spectrum (fig. 8) the luminescence region lies at 530 up to $575-580 \mathrm{~nm}$ at $\mathrm{M}=0.01$, while at $\mathrm{M}=0$ there is no luminescence. When analyzing causes of luminescence in colloids, it seems appropriate to consider a chain of processes mentioned in [57]:

$$
\begin{gathered}
\mathrm{Z} \div \mathrm{h} v_{\mathrm{ex}} \rightarrow \mathrm{Z}^{*} \\
\mathrm{Z} * \rightarrow \mathrm{Z} \div \mathrm{h} v_{\text {lum }} \\
\mathrm{Z} \div \mathrm{h} v_{\mathrm{ex}} \rightarrow \mathrm{Z}^{+}+\mathrm{e}
\end{gathered}
$$

(photoionization of defects, Z)

$$
\mathrm{Z}^{*} \rightarrow \mathrm{Z}^{+}+\mathrm{e}
$$

(thermal ionization of defects, $Z^{*}$ )

$$
\mathrm{Z}^{+}+\mathrm{e} \rightarrow\left(\mathrm{Z}^{*}\right) \rightarrow \mathrm{Z}+\mathrm{h} v_{\text {lum }}
$$

where $\mathrm{Z}$ and $\mathrm{Z}^{*}$ are basic and excited states of luminescence centers, process (6) is recovery of $Z$ state by means of electron capture. With consideration of conditions of $\mathrm{ZrO}_{2}$ nanostructure synthesis processes (2) - (6) seem very probable in the present experiment. Introduction of SDS into the initial solution may considerably increase the number of intrincic and, especially, surface defects, different vacancies, precondition appearance of new centers of absorption and luminescence in nanocrystals obtained after ablation. The indicated circumstances at $M \neq 0$ seem to determine a considerable growth of luminescence, enlargement of its spectrum to UV and red regions at $\lambda_{\text {exc }}=271 \mathrm{~nm}$, appearance of luminescence at $\lambda_{\text {exc }}=$ $510 \mathrm{~nm}$. It should be noted that the obtained data both in the wavelength range and in luminescence intensity coincide with the results of a number of research, where synthesis of zirconia was performed by different chemical methods [58, 65-67]. 


\section{Conclusions}

In the present research $\mathrm{ZrO}_{2}$ nanostructure synthesis was performed by laser ablation under conditions of increased pulse repetition rate onto zirconium target both in deionized water and aqueous solutions of SDS. That mode provides optimal conditions for productive generation of zirconia and permits a relatively flexible transformation of properties in the obtained product. XRD data and RAMAN spectra point out an interesting feature of the experiment, i.e. prevalence of dioxide amorphous phase in the product of synthesis and the presence of all three $\mathrm{ZrO}_{2}$ phases: cubic, tetragonal and monoclinic in the crystallized part of colloid. Application of surfactant SDS in the process of zirconia producing can be treated as an additional factor of stabilization for high temperature cubic and tetragonal phases. Besides, it seems that the fact of synthesizing organic-inorganic nanocomposites based on zirconium oxides or hydroxides and SDS alkyl chains was fixed in the experiment for the first time. The metal zirconium ablation in deionized water for the first time produced hollow nano and microspheres from zirconia. The authors assume that a basic mechanism for their formation is the adsorption of particles on the surface of vapor-gas bubbles and Kirkendal effect cannot be excluded, as well. There are certain references [68] that similar structures are rather promising for practical application in biomedicine, pharmacology, for developing new materials, etc.

\section{REFERENCES}

1. Bakhracheva Yu.S. Fracture Toughness Prediction by Means of Indentation Test. International Journal for Computational Civil and Structural Engineering, 2013, vol. 9, no. 3, pp. 21-24.

2. Baron A.A., Gevlich D.S., Bakhracheva Yu.S. Specific Plastic Strain Energy as a Measure of the Cracking Resistance of Structural Materials. Russian metallurgy (Metally), 2002, no. 6, pp. 587-592.

3. Batenin V.M., Bokhan P.A., Buchanov V.V., Evtushenko G.S., Kazaryan M.A., Karpukhin V.T., Klimovskii I.I., Malikov M.M. Lazery na samoogranichennykh perekhodakh atomov metallov2. V2 t. T. 2 [Lasers on Self-Terminating Transitions in Metal Atoms: 2. In 2 vols. Vol. 2]. Moscow, Fizmatlit Publ., 2011.544 p.
4. Binks B.P. Particles as Surfactants - Similarities and Differences. Current Opinion in Colloids and Interface Science, 2002, vol. 7, pp. 21-41.

5. Bluvshtein Z.M., Nizhnikova G.P., Farberovich U.V. Elektronnaya struktura i opticheskie svoystva soedineniya $\mathrm{ZrO} 2$ [Electronic Structure and Optical Properties of ZrO2]. FTT, 1990, vol. 32, iss. 3.

6. Borodina T.I., Valyano G.E., Gololobova O.A., Karpukhin V.T., Malikov M.M., Strikhanov D.A. Vliyanie lazernogo UF i vidimogo izlucheniy na strukturu i sostav sloistykh organo-neorganicheskikh nanokompozitov tsinka i medi [Effect of Laser UV and Visible Radiation on the Structure and Composition of Layered Organic-Inorganic Nanocomposites of Zinc and Copper]. Quantum Electron, 2013, vol. 43, p. 563.

7. Botta S.G., Navio J.A., Hidalgo M.C., Restrepo G.M., Litter M.I. Photocatalytic Properties of $\mathrm{ZrO} 2$ and $\mathrm{Fe} / \mathrm{ZrO} 2$ Semiconductors Prepared by SolGel Technique J. Photochem. Photobiol. A: Chemistry, 1999, vol. 129, p. 89.

8. Bozon-Verduraz F., Brayner R., Voronov V.V., Kirichenko N.A., Simakin A.V., Shafeev G.A. Obrazovanie nanochastits pri lazernoy ablyatsii metallov v zhidkostyakh [Formation of Nanoparticles by Laser Ablation of Metals in Liquids]. Quantum Electron, 2003, vol. 33, p. 714.

9. Brenner M. Single-Bubble Sonoluminescence. Rev. of Modern Phys., 2002, vol. 74, p. 425.

10. Cao G. Nanostructures and nanomaterials: Synthesis, Properties and Applications. Imperial College Press, 2004. 433 pp.

11. Chao-Hsien Wu, Chang-Ning Huang, Pouyan Shen, Shuei-Yuan Chen. J. Nanopart. Res., 2011, vol. 13, p. 6633.

12. Chen L., Mashimo T., Omurzak E., Okudera H., Iwamoto Ch., Yoshiasa A. J. Phys. Chem. C, 2011, vol. 115, p. 9370.

13. Cong Y., Li B., Yue S., Fan D., Wang X.-J. J. Phys. Chem. C, 2009, vol. 113, p. 13974.

14. Dezhi Tan, Geng Lin, Yin Liu, Yu Teng, Yixi Zhuang, Bin Zhu, Quanzhong Zhao, Jianrong Qiu. Synthesis of Nanocrystalline Cubic Zirconia Using Femtosecond Laser Ablation. J. Nanopart. Res., 2011, vol.13, p. 1183 .

15. Dezhi Tan, Yu Teng, Yin Liu, Yixi Zhuang, Jianrong Qiu. Preparation of Zirconia Nanoparticles by Pulsed Laser Ablation in Liquid. Chem. Lett., 2009, vol. 38, p. 1102. DOI: 10.1246/cl.2009.1102.

16. Emeline A., Kataeva G.V., Litke A.S., Rudakova A.V., Ryabchuk V.K., Serpone N. Photochemical and Photophysical Processes on the Surface of Wide Band Gap Insulating Materials: Powdered and Colloidal ZrO2 Sols. Langmuir, 1998, vol. 14, p. 5011.

17. Feng X., Bai Y.J., Lu B., Zhao Y.R., Yang J., Chi J.R. A Novel Reduction/Oxidation Synthetic Route 
to Cubic Zirconia Nanocrystallite. J. Cryst. Growth, 2004, vol. 262, p. 420.

18. Geethalakshmi K., Prabhakaran T., Hema J. Dielectric Studies on Nano Zirconium Dioxide Synthesized Through Co-Precipitation Process. World Academy of Sci. Eng.Tech., 2012, vol. 64, p. 150.

19. Golightly J.S., Castleman A.W. Synthesis of Zirconium Nanoparticles by Ultrafast Laser Ablation. Zeitschrift für Physikalische Chemie, 2010, vol. 221, p. 1455.

20. Kandare E., Chigwada G., Wang D., Wilkie C.A., Hossenlopp J.M. Nanostructured Layered Copper Hydroxy Dodecyl Sulfate: A potential Fire Retardant For Poly(Vinyl Ester) (PVE). Polymer Degradation and Stability, 2006, vol. 91, p. 1781.

21. Kang Suk-Joong L. Sintering: Densification, Grain Growth, and Microstructure. Elsevier Ltd., 2005.

22. Karpov S.V., Slabko V.V. Optical and Photophysical Properties of Fractal-Structured Metal Sols. Russian Academy of Sciences, Siberian Branch. Novosibirsk, 2003. (in Russian)

23. Karpukhin V.T., Malikov M.M., Valyano G.E., Borodina T.I., Gololobova O.A. Investigation of the Characteristics of a Colloidal Solution and Its Solid Phase Obtained Through Ablation of Zinc in Water by High Power Radiation From a Copper Vapor Laser. High Temperature, 2011, vol. 49, p. 681.

24.Karpukhin V.T., Malikov M.M., Valyano G.E., Borodina T.I., Gololobova O.A. Investigation of the Characteristics of a Colloidal Solution and Its Solid Phase Obtained Through Ablation of Zinc in Water by High-Power Radiation from a Copper Vapor Laser. J. Nanotechnol., 2012. Article ID: 910761. DOI: 10.1155/ 2012/910761.

25. Kumar B., Thareja R.K. Synthesis of Nanoparticles in Laser Ablation of Aluminum in Liquid. J. Appl. Phys., 2010, vol. 108, iss 6.

26. Latha Kumari Du G.H., Li W.Z., Selva Vennila R., Saxena S.K., Wang D.Z. Synthesis, Microstructure and Optical Characterization of Zirconium Oxide Nanostructures. Ceramics International, 2009, vol. 35, iss. 6, p. 2401.

27. Li C., Li M. UV Raman Spectroscopic Study on the Phase Transformation of $\mathrm{ZrO}_{2}, \mathrm{Y}_{2} \mathrm{O}_{3}-\mathrm{ZrO}_{2}$ and $\mathrm{SO}_{4}{ }^{2-}$ / $\mathrm{ZrO}_{2}$. J. Raman Spectrosc., 2002. vol. 33, p. 301-308.

28. Li X., Shimizu Y., Pyatenko A., Wang H., Koshizaki N. Tetragonal Zirconia Spheres Fabricated by Carbon-Assisted Selective Laser Heating in a Liquid Medium. Nanotechnology, 2012, vol. 23, pp. 115602.

29. Lim K.Y., Quinto-Su P.A., Klaseboer E.A., Khoo B.C., Venugopalan V.C., Ohl C. Focus: Bubbles Break Spherical Mold. Phys. Rev. E., 2010, vol. 81, pp. 016308.

30. Liu P., Cai W., Fang M., Li Zh., Zeng H., Hu J., Luo X., Jing W. Nanotechnology, 2009, vol. 20, p. 285707.
31. López E.F., Escribano V.S., Panizza M., Carnasciali M.M., Busca G.J. Vibrational and Electronic Spectroscopic Properties of Zirconia Powders. Mater. Chem., 2001, vol. 11, p. 1891.

32. Lushchik Ch.B., Lushchik A.C. Electronic Excitations With the Formation of Defects in Solids. Moscow, Nauka Publ., 1989. (in Russian)

33. Mahmoud A.K., Fadhill Z., Ibrahim Al-nassar S., Ibrahim Husein F., Akman E., Demir A. J. Mat. Sci. and Eng., 2013, vol. 6, p. 364.

34. Meskin P.E., Ivanov V.K., Baranchikov A.E., Churagulov B.R., Tretyakov Yu.D. Ultrasonically Assisted Hydrothermal Synthesis of Nanocrystalline $\mathrm{ZrO} 2, \mathrm{TiO} 2, \mathrm{NiFe} 2 \mathrm{O} 4$ and $\mathrm{Ni0}$.5Zn0.5Fe2O4 Powders. Ultrasonics Sonochemistry, 2006, vol. 13, p. 47.

35. Neppolian B., Wang Q., Yamashita H., Choi H. Appl. Catal. A: General, 2007, vol. 333, p. 264.

36. Niu K.Y., Park J., Zheng H., Alivisatos A.P. Revealing Bismuth Oxide Hollow Nanoparticle Formation by the Kirkendall Effect. Nano Lett., 2013, vol. 13, p. 5715.

37. Niu K.Y., Yang J., Kulinich S.A., Sun J., Du X.W. Hollow Nanoparticles of Metal Oxides and Sulfides: Fast Preparation via Laser Ablation in Liquid. Langmuir, 2010, vol. 26, p. 16652.

38. Ohl C.D., Lindau O., Lauterborn W. Luminescence From Spherically and Aspherically Collapsing Laser Induced Bubbles. Phys. Rev. Lett., 1998, vol. 80, p. 393.

39. Orrù R., Licheri R., Locci A. M., Cincotti A., Cao G. Consolidation/Synthesis of Materials by Electric Current Activated. Mater. Sci. Eng. R, 2009, vol. 63, p. 127.

40. Ostwald W. Lehrbuch der Allgemeinen Chemie. V. 2. Leipzig, 1896, p. 1163.

41. Pankove J.I. Optical Properties in Semiconductors. NJ, Prentice Hall, Englewood Cliffs, 1971.

42. Pesika N.S., Hu Z., Stebe K.J., Searson P.C. Quenching of Growth of ZnO.J. Phys. Chem. B, 2002, vol. 106, p. 6985.

43. Pyatenko A., Yamaguchi M., Suzuki M. Mechanisms of Size Reduction of Colloidal Silver. $J$. Phys. Chem. C, 2007, vol. 111, p. 7910.

44. QhuoQ., Margolese D.I., Ciesla U., Demuth D.G., Feng P., Gier T.E., Sieger P., Firouzi A., Chmelka B.F., Schüth F., Stucky G.D. Organization of Organic Molecules With Inorganic Molecular Species Into Nanocomposite Biphase Arrays. Chemistry of Materials, 1994, vol. 6-8, pp. 1176.

45. Ratke L., Voorhees P.W. Growth and Coarsening: Ostwald Ripening in Material Processing. Springer, 2002.

46. Ray J.C., Pramanik P., Ram S. Optical Properties of Nanocrystalline $\mathrm{Y}_{2} \mathrm{O}_{3}$. Mater. Lett., 2001, vol. 48, iss. 5, p. 281.

47. Reddy Channu V.S., Kalluru R.R., Schlesinger M., Mehring M., Holze R. Synthesis and 


\section{ТЕХНИКО-ТЕХНОЛОГИЧЕСКИЕ ИННОВАЦИИ}

Characterization of $\mathrm{ZrO}_{2}$ Nanoparticles for Optical and Electrochemical Applications. Physicochem. Eng. Aspects, 2011, vol. 386, p. 151.

48. Sahu H.R., Rao G.R. Characterization of Combustion Synthesized Zirconia Powder by UV-vis, IR and Other Techniques. Bull. Mater. Sci., 2000, vol. 23,pp. 349-354.

49. Salavati-Niasarim M., Dadkhah M., Davar F. Synthesis and Characterization of Pure Cubic Zirconium Oxide Nanocrystals by Decomposition of bis-aqua, tris-acetyl-Acetonato Zirconium(IV) Nitrate as New Precursor Complex. Inorg Chim Acta, 2009, vol. 362, pp. 3969-3974.

50. Semenova L.M., Bakhracheva Yu.S., Semenov S.V. Laws of Formation of Diffusion Layers and Solution of the Diffusion Problem in TemperatureCycle Carbonitriding of Steel. Metal Science and Heat Treatment, 2013, vol. 55, no. 1-2, pp. 34-37.

51. Shapochkin V.I., Semenova L.M., Bakhracheva Yu.S., Gyulikhandanov E.L., Semenov S.V. Effect of Nitrogen Content on the Structure and Properties of Nitrocarburized Steel. Metal Science and Heat Treatment, 2011, vol. 52, no. 9-10, pp. 413-419.

52. Shukla S., Seal S., Vanfleet R. Sol-Gel Synthesis and Phase Evolution Behavior of Sterically Stabilized Nanocrystalline Zirconia. Journal of Sol-Gel Science and Technology, 2003, vol. 27, iss. 2, p. 119.

53. Simakin A.V., Voronov V.V., Shafeev G.A. Physics of Wave Phenomena, 2007, vol. 15, p. 218.

54. Sliem M.A., Schmidt D.A., Bétard A., Kalidindi S.B., Gross S., Havenith-Newen M., Devi A., Fischer R.A. Surfactant-Induced Nonhydrolytic Synthesis of Phase-Pure $\mathrm{ZrO}_{2}$ Nanoparticles from Metal-Organic and Oxocluster Precursors. Chem. Mater., 2012, vol. 24, p. 4274.

55. Smigelskas A.D., Kirkendall E.O. Zinc Diffusion in Alpha Brass. Trans. AIME, 1947, vol. 171, p. 130.

56. Smith L.A., Duncan A., Thomson G.B., Roberts K.J., Machin D., McLeod G. Crystallisation of Sodium Dodecyl Sulphate From Aqueous Solution: Phase Identification, Crystal Morphology, Surface Chemistry and Kinetic Interface Roughening. Journal of Crystal Growth, 2004, vol. 263, iss. 1-4, pp. 480-490.

57. Stefanic G. Music S. Factors Influencing the Stability of Low Temperature Tetragonal $\mathrm{ZrO}_{2}$. Croatica Chem. Acta, 2002, vol. 75, p. 727-767.

58. Stratakis E., Zorba V., Barberoglou M., Fotakis C., Shafeev G.A. Laser Writing of Nanostructures on Bulk Al Via Its Ablation in Liquids. Appl. Surf. Sci., 2009, vol. 255, p. 5346.

59. Strekalovsky V.N., Polezhaev Yu.M., Palguev S.F. Oxides With Impurity Disordering. Composition,
Structure, Phase Transformations. Moscow, Nauka Publ., 1987. (in Russian)

60. Subbarao E.C., Maiti H.S. Oxygen Sensors and Pumps. Adv. Ceram., 1988, vol. 24, pp. 731-747.

61. Sutton D. Electronic Spectra of Transition Metal Complexes. New York, McGraw-Hill, 1968.

62. Takeda S., Ikuta Y., Hirano M., Hosono H.J. Modification of Sol-Gel-Derived Amorphous $\mathrm{Al}_{2} \mathrm{O}_{3}$ Thin Films by $\mathrm{F}_{2}$ Excimer Laser Irradiation at Ambient Temperature. Mater. Res., 2001, vol. 16, p. 1003.

63. Tok A.I.Y., Boey F.Y.C., Du S.W., Wong B.K. Mater. Sci. Eng. B., 2006, vol. 130, p. 114.

64. Varaksin A.Yu, Protasov M.V. Teplitsky Yu.S. $\mathrm{K}$ vyboru parametrov chastits dlya vizualizatsii $\mathrm{i}$ diagnostiki svobodnykh kontsentrirovannykh vozdushnykh vikhrey [To the Issues of Choice of Parameters for Particle Imaging and Diagnostics Free Concentrated Air Vortices]. High Temperature, 2014, vol. 52, no. 4, p. 581.

65. Yan Z., Bao R., Chrisey D.B. Excimer Laser Ablation of a Pt Target in Water: the Observation of Hollow Particles. Nanotechnology, 2010, vol. 21, p. 145609.

66. Yan Z., Bao R., Huang Y., Chrisey D.B. Hollow Particles Formed on Laser-Induced Bubbles by Excimer Laser Ablation of Al in liquid. J. Phys. Chem. C, 2010, vol. 114, p. 11370.

67. Yan Z., Bao R., Wright R.N., Chrisey D.B. Hollow Nanoparticle Generation on Laser-Induced Cavitation Bubbles Via Bubble Interface Pinning. Appl. Phys. Lett., 2010, vol. 97, p. 124106.

68. Yan Z., Bao. R., Huang Y., Caruso A.N., Qadri S.B., Dinu C.Z., Chrisey D.B. Excimer Laser Production, Assembly, Sintering, and Fragmentation of Novel Fullerene-Like Permalloy Particles In Liquid. J. Phys. Chem. C, 2010, vol. 114, pp. 3869-3873.

69. Yang G.W. Laser Ablation in Liquids: Applications in the Synthesis of Nanocrystals. Progress in Material Science, 2007, vol. 52, pp. 648-698.

70. Yang J., Hou J., Du X. School of Materials Science and Engineering. Tianjin, Tianjin University, 2013,p. 300072.

71. Yavas O., Leiderer P., Park H.K., Grigoropoulos C.P., Poon C.C., Leung W.P, Do N., Tam A.C. Optical Reflectance and Scattering Studies of Nucleation and Growth of Bubbles at a Liquid-Solid Interface Induced by Pulsed Laser Heating. Phys Rev Lett., 1993, vol. 70, pp. 1830-1833.

72. Zhou J., Wu W., Caruntu D., Yu M.H., Martin A., Chen J. F., O`Connor C.J., Zhou W.L. Investigation of Structures and Drug Release of Magnetic Hollow Silica Nanospheres. J. Phys. Chem. C, 2007, vol. 111 (47), p. 17473. 


\section{СТРУКТУРНЫЕ, МОРФОЛОГИЧЕСКИЕ \\ И ОПТИЧЕСКИЕ СВОЙСТВА НАНОПРОДУКТОВ ЦИРКОНИЯ ПРИ ЛАЗЕРНОЙ АБЛЯЦИИ В ВОДЕ И ВОДНЫХ РАСТВОРАХ}

\section{Карпухин Вячеслав Тимофеевич}

Доктор технических наук, главный научный сотрудник лаборатории физического моделирования двухфазных течений, ФГБУН Объединенный институт высоких температур vtkarp@gmail.com ул. Ижорская, 13, 125412 г. Москва, Российская Федерация

\section{Маликов Михаил Максимович}

Доктор технических наук, ведущий научный сотрудник лаборатории физического моделирования двухфазных течений, ФГБУН Объединенный институт высоких температур vtkarp@gmail.com ул. Ижорская, 13, 125412 г. Москва, Российская Федерация

\section{Бородина Татьяна Ивановна}

Кандидат физико-математических наук старший научный сотрудник лаборатории ударно-волновых воздействий, ФГБУН Объединенный институт высоких температур vtkarp@gmail.com ул. Ижорская, 13, 125412 г. Москва, Российская Федерация

\section{Вальяно Георгий Евгеньевич}

Старший научный сотрудник лаборатории ударно-волновых воздействий, ФГБУН Объединенный институт высоких температур vtkarp@gmail.com ул. Ижорская, 13, 125412 г. Москва, Российская Федерация

\section{Гололобова Олеся Александровна}

Стажер - исследователь лаборатории физического моделирования двухфазных течений, ФГБУН Объединенный институт высоких температур vtkarp@gmail.com ул. Ижорская, 13, 125412 г. Москва, Российская Федерация

\section{Стриканов Дмитрий Андреевич}

Аспирант лаборатории физического моделирования двухфазных течений, ФГБУН Объединенный институт высоких температур vtkarp@gmail.com ул. Ижорская, 13, 125412 г. Москва, Российская Федерация 
Аннотация. В статье были исследованы структурные, морфологические и оптические свойства нанопродуктов лазерной абляции циркония в воде и водных раствоpax. Было показано формирование диоксида циркония на основе полых нано- и микроструктур. Предполагается, что при абляции образуются парогазовые пузырьки, которые могут служить для производства полых нанокомпозитов.

Ключевые слова: лазерная абляция, наноструктуры металла, диоксид циркония, спектры комбинационного рассеяния, парогазовые пузырьки. 